\title{
The mode of action of antimalarial endoperoxides
}

Steven R. Meshnick Department of Epidemiology, University of Michigan School of Public Heath, Ann Arbor, MI 48109, $U S A$

\section{Abstract}

The mechanism of action of artemisinin appears to involve two steps. In the first step, activation, intra-parasitic iron catalyses the cleavage of the endoperoxide bridge and the generation of free radicals. In the second step, alkylation, the artemisinin-derived free radical forms covalent bonds with parasite proteins.

\section{Introduction}

Several classes of compounds containing endoperoxide (dioxygen) bridges have antimalarial activity, including artemisinin derivatives (reviewed by BUTLER \& Wu, 1992), trioxanes (reviewed by JEFFORD et al., 1992), and yingzhaosu derivatives ( $R$. Ridley, Hoffman-LaRoche, personal communication) (Fig. 1). The best understood

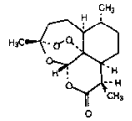

Artemisinin

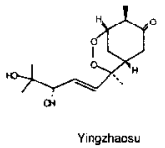

Yingzhac

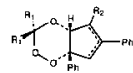

Trioxane
Fig. 1. Antimalarial endoperoxides.

of these compounds, in terms of mechanism, are the artemisinin derivatives. In this report, evidence is summarized to show that the antimalarial action of artemisinin (and, by inference, other endoperoxides) depends on 2 sequential steps. The first step, activation, comprises the iron-mediated cleavage of the endoperoxide bridge to generate an unstable organic free radical and/or other electrophilic species. The second step, alkylation, involves the formation of covalent adducts between the drug and malarial proteins (Fig. 2).

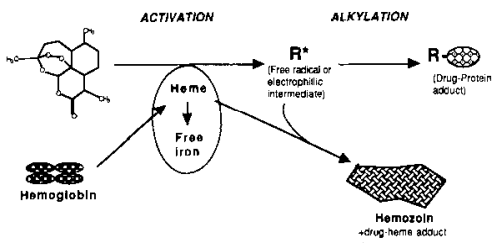

Fig. 2. Proposed mechanism of action of artemisinin.

\section{Activation}

A free radical is a short-lived and highly reactive molecule that contains an unpaired electron. While many of the biologically important free radicals are partially reduced forms of molecular oxygen $\left(\mathrm{O}_{2}-, \mathrm{HO} \cdot\right)$, evidence is accumulating in a number of systems that carboncentred free radicals play important roles (HALLIWELL \& GUTTERIDGE, 1989).

Iron has long been known to catalyse the decomposition of both hydrogen peroxide and organic peroxides into free radicals. This catalytic activity is a property of both free iron and haem-bound iron (HALLIWELL \& GUTTERIDGE, 1989). With this as background, the observation that deoxyartemisinin, which lacks the endoperoxide bridge, has no antimalarial activity (CO-OPERATIVE RESEARCH GROUP ON QINGHAOSU AND ITS DERIVATIVES AS ANTIMALARIALs, 1982) led my colleagues and I to investigate whether iron-catalysed cleavage of the endoperoxide bridge might play a role in the drug's mechanism of action.
Indeed, iron readily caralyses the cleavage of artemisinin's endoperoxide bridge. Evidence for the haem-catalysed decomposition of artemisinin was obtained by cyclic voltammetry (ZHANG et al., 1992). At least one of the products of the iron-mediated decomposition is a free radical, which was demonstrated by electron paramagnetic resonance spectroscopy (MESHNICK $e t$ al., 1993). Haem also catalyses the generation of radicals from artemisinin (F. Kuypers, unpublished results). The mechanism of iron-mediated decomposition has recently been elucidated (PosNer \& OH, 1992). In aggregate, these data indicate that iron activates artemisinin into a free radical.

There is strong evidence that the antimalarial activities of these drugs depend on the generation of free radical intermediates. Free radical scavengers such as ascorbic acid and vitamin $\mathrm{E}$ antagonize the antimalarial activities of the drug both in vitro (KRUNGKRAI \& YUTHAVONG, 1987; MESHNICK et al., 1989) and in vivo (LEVANDER et al., 1989). However, the free radical intermediate, once formed, may structurally rearrange to produce other reactive and electrophilic intermediates (POSNER \& OH, 1992).

Drug activation by iron and haem may explain why endoperoxides are selectively toxic to malaria parasites. Malaria parasites live in a 'sea' of haem-iron (the red cell is $95 \%$ haemoglobin, or $20 \mathrm{~mm}$ haem), which they eventually convert into insoluble haemozin. The observation that chloroquine-resistant Plasmodium berghei, which lacks visible hacmozoin, is resistant to artemisinin (PETERS et al., 1986) suggests that active haemozoin biosynthesis is essential for drug activity.

There are several different iron pools in the infected red blood cell which might be responsible for drug activation (Fig. 2). In the food vacuole, haemoglobin is in the process of being broken down, releasing haem. The haem, in turn is in the process of being polymerized into haemozoin. There may also be free iron formed $(\mathrm{H}$. Ginsburg, Hebrew University, personal communication). Finally, there are haemoproteins (i.e., cytochromes) in the mitochondria. Which of these iron pools is responsible for catalysing the decomposition of artemisinin in vivo?

In vitro, artemisinin reacts poorly or not at all when mixed with either haemoglobin or haemozoin, suggesting that these pools may not be important. In contrast, artemisinin is activated quite well by haem and free iron (MESHNICK el al., 1991, 1993; POSNER et al., 1992; ZHANG et al., 1992). The observation that chloroquine, which binds haem (CHOU et al., 1980), antagonizes the antimalarial activity of artemisinin against $P$. falciparum (see STAHEL $e t a i ., 1988$ ) suggests that the free haem pool may be important. Similarly, the observation that iron chelators, which bind free iron, are antagonistic, suggests that free iron may be important (KAMCHUNWUNGPAISAN et al., 1992; MESHNICK et al, 1993). However, some iron chelators also bind haem. Thus, it appears that the transient pools of haem and free iron may be responsible for activating artemisinin in vivo.

\section{Alkylation}

After the drug is converted to a reactive free radical it can then form covalent bonds with proteins. The reac- 
tions of both $\left.{ }^{[14} \mathrm{C}\right]$ artemisinin and $\left[{ }^{3} \mathrm{H}\right]$ dihydroartemisinin with proteins have been studied in 2 model systems-human serum and isolated red cell membranes.

Radiolabelled artemisinin covalently reacts with human serum albumin in a time-dependent fashion, predominantly forming bonds with free amino groups (YANG et al., 1993). There are both iron-dependent and iron-independent reactions. The covalent nature of the adduct was demonstrated by sodium dodecyl sulphatepolyacrylamide gel electrophoresis and by electrospray mass spectrometry (YANG et al., 1993). Radiolabelled drug is also taken up by isolated red cell membranes, where it forms covalent bonds with various membrane proteins such as $\alpha$-spectrin, $\beta$-spectrin, band 3 , band $4 \cdot 1,4 \cdot 2$, actin and glyceraldehyde phosphate dehydrogenase. In contrast, when artemisinin is incubated with intact erythrocytes, there is no uptake or protein alkylation (W. Asawamahasakda et al., paper submitted for publication).

Artemisinin also forms covalent adduct with haem both in solution and in vivo (MESHNICK et al., 1991). However, the alkylation of haem appears to have little biological significance since, when infected red blood cells are exposed to high levels of artemisinin, there is no diminution in haemozoin content (C.-C. Chang et al., paper submitted for publication).

Once taken into the parasite, $\left[{ }^{3} \mathbf{H}\right]$ dihydroartemisinin concentrates in the haemozoin. In addition, several malaria-specific proteins are alkylated (W. Asawamahasakda et al., paper submitted for publication).

\section{Other effects of artemisinin}

Electron micrographs have demonstrated that the earliest pathological effects of artemisinin are on parasite membranes and mitochondria, as well as on food vacuoles (MAENo et $\alpha l$., 1993). The effects on membranes and mitochondria may be secondary to the toxic effects of the drug on the food vacuole, or they may be due to activation and alkylation reactions occurring at those sites.

Very high concentrations of artemisinin $(0.1-1 \mathrm{mM})$ cause oxidation of red blood cell membrane proteins and decreases in red cell deformability, especially in the presence of exogenous haem (SCOTT et al, 1989; MESHNICK et al., 1991, 1993), suggesting that the drug may affect plasma membrane function in infected erythrocytes. However, no such effect has been seen at therapeutic drug concentrations.

\section{Effects of endoperoxides on the host}

The mechanisms described above may also explain some of the drug's effects on the host (BREWER et al., 1992). Iron-mediated activation of endoperoxides may play a role in host toxicity since an iron chelator has been shown to prolong survival in mice given lethal doses of artemisinin (MESHNICK et al., I993). In addition, the facile reactions between artemisinin and host proteins may play a role in the rapid disappearance of the drug from the blood-stream.

\section{Summary}

The endoperoxides represent a new class of antimalarial agents, which are entirely unrelated to any of the other currently available drugs. Insight into their mechanisms of action can aid in the design of new and more effective derivatives.

\section{Acknowledgements}

This work was supported by grants from the UNDP/World Bank/WHO Special Programme for Research and Training in Tropical Diseases and from the US National Institute of Health (AI26848).

\section{References}

Brewer, T. G., Grate, S. J., Peggins, J. O., Weina, P. J., Petras, J. M., Levine, B. S., Heiffer, M. H. \& Schuster, B. G. (1992). Fatal neurotoxicity due to arteether and artemether. American foumal of Tropical Medicine and Hygiene, 47, 93 (abstract).

Butler, A. R. \& Wu, Y. -L. (1992). Artemisinin (qinghaosu); a new type of antimalarial drug. Chemical Society Reviews, [1992], 85-90.

Chou, A, Chevli, R. \& Fitch, C. D. (1980). Ferriprotoporphyrin IX fulfills the criteria for identification as the chloroquine receptor of malaria parasites. Biochemistry, 19, 1543-1549.

Co-operative research group on qinghaosu and its derivatives as antimalarials (1982). Chemical studies on qinghaosu (artemisinine). 7oumal of Traditional Chinese Medicine, 2, 3-8.

Halliwell, B. \& Gutteridge, J. M. C. (1989). Free Radicals in Biology and Medicine, 2nd edition. Oxford: Clarendon Press.

Jefford, C. W., Misra, D., Rossier, J. -C., Kamalaprija, P., Burger, U., Mareda, J., Bernardinelli, G., Feters, W., Robinson, B. L., Milhous, W. K., Zhang, F., Gosser, D. K., ir \& Meshnick, S. R. (1992). Cyclopenenteno-1,2,4-trioxanes as effective antimalarial surrogates of artemisinin. In: Perspectives in Medicine Chemistry, Testa, B., Kyburz, E., Fuhrer, W. \& Giger, R. (editors). Basel: Verlag Helvetica Chimica Acta, pp. 459-472.

Kamchunwungpaisan, S., Vanitcharuen, N. \& Yulhavung, Y. (1992). The mechanism of action of artemisinin (qinghaosu). In: Lipid-Soluble Antioxidants: Biochemistry and Clinical Applications, Ong, A. S. H. \& Packer, L. (editors) Basel: Birkhauser-Verlag, pp. 363-372.

Krungkrai, S. R. \& Yuthavong, Y. (1987). The antimalarial action of qinghaosu and artesunate in combination with agents that modulate oxldant stress. Transactions of the Royal Society of Tropical Medicine and Hygiene, 81, 710-714.

Levander, O. A., Ager, A. L., Morris, V. C. \& May, R. G. (1989). Qinghaosu, dietary vitamin $E$, selenium, and cod-liver oil: effect on the susceptibility of mice to the malarial parasite, Plasmodium yoelii. American Journal of Clinical Nutrtion, $\mathbf{5 0}$, $346-352$.

Maeno, Y., Toyoshima, I., Fujıoka, H., Ito, Y., Meshnick, S. R., Benakis, A., Milhous, W. K. \& Aikawa, M. (1993). Morphological effects of artemisinin in Plasmodium falciparum. American Joumal of Tropical Medicine and Hygiene, 49, 485491.

Meshnick, S. R., Tsang, T. W., Lin, F. B., Pan, H. Z., Chang, C. N., Kuypers, F., Chiu, D. \& Lubin, B. (1989). Activated oxygen mediates the antumalarial activity of qinghaosu. Progress in Clinical and Biological Research, 313, 95-104

Meshnick, S. R., Thomas, A., Ranz, A., Xu, C. M. \& Pan, H. Z. (1991). Artemisinin (qinghaosu): the role of intracellular hemin in its mechanism of antimalarial action. Molecular and Biochemical Parasitology, 49, 181-190.

Meshnick, S. R., Yang, Y. Z., Lima, V., Kuypers, F., Kamchonwongpaisan, S. \& Yuthavong, Y. (1993). Iron-dependent free radical generation and the antimalarial artemisinin (qinghaosu). Antimicrobial Agents and Chemotherapy, 37, 1108-1114.

Peters, W., Lin, L., Robinson, B. L. \& Warhurst, D. C. (1986). The chemotherapy of rodent malaria, XL. The action of artemisinin and related sesquiterpenes. Annals of Tropical Medicine and Parasitology, 80, $483-489$.

Posner, G. \& Oh, C. H. (1992). A regiospecifically oxygen-18 labelled 1,2,4-trioxane: a simple chemical model system to probe the mechanisms for the antimalarial activity of artemisinin (qinghaosu). Fournal of the American Chemical Society, $114,8328-8329$.

Scott, M. D., Meshnick, S. R. Williams, R. A, Chiu, D., Pan H. Z., Lubin, B. \& Kuypers, F. (1989). Qinghaosu-mediated oxidation in normal and abnormal erythrocytes. Foumal of Laboratony and Clinical Medicine, 114, 401-406.

Stahel, E., Druilhe, P. \& Gentilini, M. (1988). Antagonism of chloroquine with other antimalarials. Transactions of the Royal Society of Tropical Medicine and Hygiene, 82, 221.

Yang, Y. Z., Asawamahasalkda, W. \& Meshnick, S. R. (1993). Alkylation of human albumin by the antimalarial artemisinin. Biochemical Pharmacology, 46, 336-339.

Zhang, F., Gosser, D. \& Meshnick, S. R. (1992), Hemin-catalysed decomposition of artemisinin (qinghaosu). Biochemical Pharmacology, 43, 1805-1809. 